\title{
POLA SPASIAL DAN TEMPORAL JENIS AWAN DI SELATAN INDONESIA BERDASARKAN KANAL IR1 HIMAWARI-8 PADA PERIODE MUSIM HUJAN
}

\author{
Spatial and Temporal Pattern of Cloud Types in Southern Indonesia based on \\ HIMAWARI-8 IR1- Band during Rainy Season
}

\author{
Robi Muharsyah ${ }^{1)^{*}}$, Novi Fitrianti ${ }^{1)}$ \\ 1) Pusat Informasi Perubahan Iklim. Badan Meteorologi Klimatologi dan Geofisika, \\ Jl. Angkasa 1 No.2, Kemayoran, Jakarta Pusat, 10720 \\ Email: robi.muharsyah@gmail.com
}

\begin{abstract}
Intisari
Banyak kajian yang telah membahas perkiraan jenis awan atau intensitas curah hujan menggunakan citra satelit cuaca HIMAWARI-8, namun umumnya dalam skala wilayah yang kecil (pada satu kota) dan rentang waktu yang singkat (pengamatan beberapa jam). Penelitian ini bertujuan untuk mengidentifikasi pola spasial dan temporal jenis awan yang diduga dari kanal IR1 HIMAWARI-8, pada cakupan wilayah yang lebih luas, yaitu di bagian selatan Indonesia (80E150E;15S-1N), serta pada periode pengamatan lebih lama (musim hujan 2017/2018). Metode Convective Stratiform Technique (CST) dipilih untuk menduga jenis awan Stratiform dan Cumuliform. Hasilnya secara temporal, awan Stratiform lebih dominan muncul pada sore hingga malam hari. Kemudian secara spasial, bagian barat di selatan Indonesia selalu diliputi awan Stratiform dari pagi hingga malam hari. Berdasarkan jumlah awan Cumuliform, puncak musim hujan terjadi pada 21-31 Januari 2018. Penelitian ini juga menunjukkan bahwa juga jumlah pixel awan Cumuliform berkorelasi kuat $(r>0,75)$ terhadap jumlah pixel citra Global Satellite Mapping of Precipitation Near Real Time (GSMaP) dengan intensitas curah hujan >0,1 mm/jam. Terakhir, penelitian ini memberikan suatu pendekatan baru untuk mengukur akurasi antara jenis awan yang diduga dari kanal IR1 HIMAWARI-8 dengan terjadinya curah hujan di suatu wilayah yang dapat dipakai untuk mengevaluasi fenomena pada skala meso seperti Mesoscale Convective Complex (MCC).
\end{abstract}

Kata Kunci: HIMAWARI-8, CST, Pola Spasial dan Temporal, Musim Hujan

\begin{abstract}
Many studies have discussed an estimation of cloud types or rainfall intensity using HIMAWARI-8 weather satellite imagery; however, they are still limited in a small area (at a certain region) and a short period (few hours). This study aims to identify the spatial and temporal patterns of cloud types, estimated from the IR1 band of HIMAWARI-8 satellite imagery, in a larger area, particularly in southern Indonesia (80E-150E;15S-1N) as well as for longer observation (rainy season 2017/2018). The Convective Stratiform Technique (CST) method is used to estimate the Stratiform and Cumuliform cloud. Temporally, Stratiform clouds appear dominantly from afternoon to evening. Furthermore, spatially, southern Indonesia's western region, is always covered with Stratiform clouds from morning to evening. According to the number of Cumuliform clouds, the rainy season's peak occurs during January $21-31,2018$. The study also reveals that the amount of Cumuliform clouds is strongly correlated ( $r>0.75$ ) towards Global Satellite Mapping of Precipitation Near RealTime (GSMaP) imagery pixel with rainfall $>0.1 \mathrm{~mm} / \mathrm{hour}$. Finally, this study provides a new approach to measure the accuracy between cloud types estimated from band IR1 of HIMAWARI-8 and the occurrence of rainfall in a certain area that can be used to evaluate mesoscale phenomena such as the Mesoscale Convective Complex (MCC).
\end{abstract}

Keywords: HIMAWARI-8, CST, Spatial and Temporal Pattern, Rainy Season 


\section{PENDAHULUAN}

Satelit cuaca digunakan untuk melakukan pengamatan kondisi atmosfer secara remote sensing. Citra satelit cuaca terekam dalam sensor yang menggunakan kanal Visible (VIS) dan Infra-Red (IR). Citra tersebut mampu memberikan gambaran liputan awan di suatu wilayah (Kushardono, 2012). Pada dasarnya, prinsip kerja satelit cuaca adalah dengan memperhitungkan kondisi suhu puncak awan yang teramati oleh sensor pada satelit tersebut. Oleh karena itu, citra satelit cuaca umumnya dimanfaatkan untuk menentukan jenis awan atau menduga intensitas curah hujan di suatu lokasi pada waktu tertentu (Kusumawati et al., 2008; Kushardono, 2012).

Penyebab terjadinya hujan sangat berkaitan erat dengan keberadaan dan jenis awan di suatu wilayah (Wirjohamidjojo \& Swarinoto, 2007; Tjasyono HK., 2012). Berdasarkan pembentukan awan secara vertikal, awan diklasifikasikan menjadi dua jenis, Stratiform dan Cumuliform (Tjasyono HK., 2012). Awan Stratiform umumnya menghasilkan hujan dengan intensitas ringan hingga sedang, sedangkan awan Cumuliform atau dikenal juga dengan awan konvektif, umumnya menghasilkan hujan dengan intensitas lebat dan berlangsung dalam waktu singkat. Kedua jenis awan ini dapat diidentifikasi melalui citra satelit cuaca dengan melihat bentuk, tekstur, suhu puncak awan, kecerahan, pergerakan, serta perubahannya terhadap waktu (Kusumawati et al., 2008; Kushardono, 2012; Putri, 2016; Paski et al., 2017; Hastuti \& Azzahra, 2017; Rizkiafama et al., 2019).

Kajian terkait perkiraan jenis awan atau intensitas curah hujan dari citra satelit cuaca telah banyak dilakukan (Kusumawati et al., 2008; Parwati et al., 2009; Mikuš \& Strelec Mahović, 2013). Pada awalnya kajian-kajian tersebut memanfaatkan citra Multi-functional Transport SATellite (MTSAT). Kemudian setelah diluncurkan nya generasi terbaru satelit cuaca, yaitu HIMAWARI-8, yang dilengkapi sensor Advanced Himawari Imager (AHI) dengan spesifikasi resolusi temporal, spektral dan spasial lebih baik dari MTSAT (https://www.jma.go.jp/ima/jma-eng/satellite/ himawari89.html), maka beberapa tahun terakhir ini telah banyak peneliti memanfaatkan citra HIMAWARI-8 untuk berbagai kepentingan penelitian di bidang cuaca dan iklim (Putri, 2016; Paski et al., 2017; Hastuti \& Azzahra, 2017; Wicaksono et al., 2018; Kharisma \& Widomurti, 2018; Rizkiafama et al., 2019; Mulsandi et al., 2020).

Kajian perkiraan jenis awan ataupun intensitas curah hujan dari citra HIMAWARI-8 di wilayah Indonesia diantaranya dilakukan oleh Putri, 2016, yang menduga jenis awan untuk analisis kejadian hujan lebat di Nabire Papua sama seperti Paski et al., 2017 namun di wilayah Lampung. Kemudian Hastuti \& Azzahra, 2017 menduga hujan di Kalianget, Madura, Jawa Timur dengan metode Auto-Estimator. Wicaksono et al., 2018 menganalisis hujan fenomena hujan es dari citra HIMAWARI-8 di Lubuk Linggau, Sumatera Selatan. Kharisma \& Widomurti, 2018 mengkaji kejadian hujan lebat di Banjarnegara, Jawa Tengah. Kemudian, Rizkiafama et al., 2019 menganalisis kejadian banjir di kota Padang, Sumatera Barat dan yang terbaru Mulsandi et al., 2020, mengevaluasi citra HIMAWARI-8 dengan metode perkiraan hujan modify Convective Stratiform Technique (CSTm) untuk kajian di sekitar Jakarta.

Meskipun kajian-kajian tersebut sukses memanfaatkan citra HIMAWARI-8 untuk perkiraan jenis awan atau intensitas curah hujan di wilayah kajiannya masing-masing, akan tetapi penelitian yang dilakukan umumnya bersifat lokal pada satu wilayah yang cakupannya relatif kecil (misal pada satu kota) dan hanya dilakukan pada satu waktu (misal pada rentang beberapa jam) saja. Kajian tersebut tidak mengungkap bagaimana pola spasial jenis awan yang diduga dari citra HIMAWARI-8 pada wilayah yang lebih luas, dan bagaimana pola temporal yang menggambarkan kondisi rata-rata untuk rentang waktu yang lama, seperti pada rentang $30-90$ hari.

Identifikasi jenis awan pada skala yang luas dapat dipakai untuk mengetahui Mesoscale Convective Complex (MCC) yang merupakan salah satu jenis dari fenomena Mesoscale Convective Systems (MCS) yaitu, sistem awan kumulonimbus yang menghasilkan area hujan berdekatan dengan jarak $100 \mathrm{~km}$ atau lebih (Muhlis \& Mulsandi, 2017; Septiadi \& Nugraha, 2019). Oleh karena itu kajian ini bertujuan untuk mengidentifikasi pola spasial dan temporal jenis awan yang diduga dari kanal IR1 citra HIMAWARI-8, menggunakan cakupan wilayah yang lebih luas, (di bagian selatan wilayah Indonesia) dan menggunakan waktu lebih panjang (selama periode musim hujan). Wilayah bagian selatan Indonesia yang dimaksud adalah wilayah yang berada di bawah garis ekuator, meliputi pulau Jawa, Bali, Nusa tenggara, serta bagian selatan: pulau Sumatera, pulau Sulawesi dan pulau Papua. Wilayah ini bertipe A (Aldrian \& Susanto, 2003) atau disebut juga wilayah hujan monsunal serta mempunyai periode musim hujan dari Desember hingga Januari (DJF). Di wilayah ini sering ditemukan jenis awan Stratiform dan Cumuliform yang menyebabkan terjadinya hujan konvektif selama periode DJF (Kusumawati et al., 2008). Penelitian ini dibatasi pada pola spasial dan temporal jenis awan yang teridentifikasi dari kanal IR1 citra HIMAWARI-8, namun tidak membahas secara spesifik hubungannya dengan MCC. 


\section{DATA DAN METODE}

\subsection{Data}

Data yang digunakan pada penelitian ini adalah band 13 atau kanal IR1 dari citra HIMAWARI-8, yang termasuk dalam kategori Thermal Infra-Red (TIR). Data utama pada penelitian ini adalah citra dengan resolusi temporal satu jam yang disediakan gratis oleh Kochi University, Jepang dan dapat diakses di http://weather.is.kochi-u.ac.jp/sat/GAME/. Jenis citra per satu jam ini terdiri dari dua bagian, yaitu: data kanal IR1 dan tabel kalibrasi IR1, keduanya digunakan secara bersamaan (http://weather.is.kochi-u.ac.jp/sat/CAL/). Citra HIMAWARI-8 mempunyai resolusi spasial $0,5^{\circ} \times 0,5^{\circ}$ dengan akusisi wilayah mencakup 20S$70 \mathrm{~N}$ dan 20E-150E (1800×1800 pixel). Selain data utama, digunakan juga data kanal IR1 dengan resolusi temporal lebih tinggi yaitu per-10 menit. Sebagai contoh dipilih citra pengamatan yang tersedia untuk tanggal 11 Januari 2018. Citra ini sudah diolah sedemikian rupa agar dapat diproses menggunakan aplikasi SATellite Animation and Interactive Diagnosis (SATAID) dan disediakan melalui portal File Transfer Protocol oleh Bidang Satelit Badan Meteorologi Klimatologi dan Geofisika, BMKG (dengan akses terbatas). Kanal IR1 per-10 menit ini hanya dipakai sebagai data dukung terhadap data utama untuk melihat kesamaan hasil identifikasi jenis awan yang diproses dengan SATAID.

Penelitian ini juga menggunakan data curah hujan dari citra satelit Global Satellite Mapping of Precipitation Near Real Time (GSMaP) dengan resolusi temporal per satu jam dan resolusi spasial $0,1^{\circ} \times 0,1^{\circ}$ serta dapat diakses secara gratis di https://sharaku.eorc.jaxa.jp/GSMaP/. Sebanyak 90 citra HIMAWARI-8 dan GSMaP di unduh untuk rentang periode musim hujan, DJF 2017/2018 atau selama 90 hari dari 1 Desember (Des) 2017 hingga 28 Februari (Feb) 2018.

\subsection{Metode}

Identifikasi pola spasial dan temporal jenis awan selama periode musim hujan di selatan Indonesia dilakukan beberapa tahap. Pertama, perkiraan jenis awan menggunakan metode Convective Stratiform Technique (CST). Singkatnya, menurut Adler \& Negri (1988) CST menggunakan model awan 1-Dimensi untuk mencari hubungan antara suhu puncak awan dan intensitas curah hujan, kemudian hubungan suhu puncak awan dan luas area awan hujan. Bagian penting pada CST adalah menentukan inti konvektif atau disebut local minima of Temperature Black Body (TBB) yang bertujuan untuk mencari rain rate dan area hujan di suatu lokasi. Pada penelitian ini metode CST diadopsi penuh (tanpa modifikasi) dari Adler \& Negri,
(1988), terdapat beberapa langkah yang dilakukan:

1. Mengidentifikasi nilai $T_{\min }$ atau kandidat inti konvektif dalam 3x3 pixel atau skema 4 grid data kanal IR1 (lihat ilustrasi Gambar 1)

2. Menggunakan persamaan (1) untuk menghitung slope parameter (S) dengan mengurangkan rata-rata nilai TBB disekitar inti konvektif terhadap inti konvektif $\left(T_{\min }\right)$;

$$
\begin{array}{r}
S=k\left(T_{i-1, j}+T_{i+1, j}+T_{i, j-1}\right. \\
+T_{i, j+1}-4 T_{i, j}
\end{array}
$$

3. Menentukan nilai $T_{\min }$ yang diidentifikasi sebagai inti konvektif dengan slope yang memenuhi persamaan (2):

$$
S \geq \exp \text { [0.0826(Tmin - 207)] }
$$

4. Menentukan area hujan konvektif (AC) menggunakan persamaan (3)

$$
\ln \left(A_{c}\right)=a T_{\min }+b
$$

dengan $a=-0,0492$ dan $b=15,27$ adalah konstanta indeks

5. Menentukan curah hujan dari awan Cumuliform dan Stratiform dari tiap grid atau pixel menggunakan persamaan (4) dan (5) Convective rainfall $(\mathrm{mm})$

$$
\begin{array}{r}
=c(A c / A) T \cdot R c \\
\text { Stratiform rainfall }(\mathrm{mm}) \\
=s(A s / A) T . R s
\end{array}
$$

dimana, $S$ Slope Parameter (Parameter penentu jenis awan), $C$ jumlah pixel konvektif dalam 1 grid, $A c$ area hujan konvektif, $A$ ratarata area yang dilingkupi oleh tiap pixel, $T$ rata-rata periode, $R c$ intensitas curah hujan konvektif, $s$ jumlah pixel stratiform dalam 1 grid, As area hujan stratiform, dan $R s$ Intensitas curah hujan stratiform.

Langkah [1] - [5] dilakukan untuk semua pixel kanal IR1 HIMAWARI-8. Namun, hanya bagian selatan Indonesia yang dipilih untuk dianalisis di penelitian ini, domain 80E-150E dan 15S-1N (lihat Gambar 2).

Tahap kedua, membandingkan jenis awan yang didapat dari metode CST dengan metode enhancement di aplikasi SATAID. Enhancement adalah proses penajaman untuk memperbaiki tampilan citra sehingga mempermudah pengguna dalam menginterpretasi dan menganalisa secara manual objek-objek yang ada pada tampilan citra (Jensen \& Lulla, 1987). Terdapat beberapa teknik dalam proses penajaman citra ini, pada penelitian ini digunakan teknik komposit Red Green Blue (RGB) yang direkomendasikan oleh World Meteorological Organization (WMO), seperti: Day Convective Storm RGB for detection of Cumulonimbus Cloud (http://www.data.jma.go.jp/mscweb/en/VRL/VLab RGB/RGBimage.html) dan juga telah digunakan pada kajian Paski et al. (2017).

Tahap ketiga dari penelitian ini adalah melakukan analisis statistik deskriptif dalam bentuk peta (spasial) dan grafik (temporal), untuk mendapatkan pola spasial dan temporal dari jenis awan yang telah diduga dengan metode 
CST. Pada bagian ini juga ditampilkan diagram Hovmoller (grafik hubungan pola spasial dan temporal) untuk mengungkap fenomena Madden Julian Oscilation (MJO) yang aktif di Bumi Maritim Indonesia (BMI) pada periode DJF (Madden \& Julian, 1972).

Hasil identifikasi jenis awan di evaluasi dengan cara "eyeball" verification. Kemudian juga dilengkapi dengan uji korelasi untuk menunjukkan akurasi perkiraan metode CST terhadap pola hujan yang ditunjukkan oleh citra satelit GSMaP. Tingkat akurasi berdasarkan nilai korelasi ( $r$ ) pada penelitian ini dikelompokkan menjadi lima kelas: Sangat Kuat $(0,8<r \leq 1,0)$, Kuat $(0,6<r \leq 0,8)$, Sedang $(0,4<r \leq 0,6)$, Lemah $(0,2<r \leq 0,4)$, dan Sangat Lemah $(0<r \leq 0,2)$. Penjelasan teknik "eyeball" verification dan persamaan menghitung nilai korelasi lebih jelas dapat dilihat pada Forecast Verification methods Across Time and Space Scales (https://www.cawcr.gov.au/ projects/verification/).

\section{HASIL DAN PEMBAHASAN}

\subsection{Perbandingan Metode CST dan Metode Enhancement aplikasi SATAID}

Sebelum dihitung menggunakan metode CST umumnya nilai TBB pada data kanal IR1 berkisar antara $150^{\circ} \mathrm{C}-350^{\circ} \mathrm{C}$ (lihat Gambar 3). Warna pixel yang sangat terang pada Gambar 3 menunjukkan nilai TBB yang rendah dan berasosiasi dengan awan Cumuliform (warna merah) pada Gambar 4 sebagai hasil perkiraan jenis awan dengan metode CST pada tanggal 1 Desember 2017 jam 00 UTC. Hasil seperti Gambar 4 ini juga diperoleh untuk semua citra pada rentang waktu dari 1 Des 2017-28 Februari 2018 jam 00 UTC-23 UTC atau sebanyak 90 hari x 24 jam $=2160$ peta (tidak semua Gambar ditampilkan pada tulisan ini).

Bagian pertama, identifikasi pola spasial jenis awan pada periode musim hujan DJF 2017/2018, diawali dengan membandingkan jenis awan hasil perkiraan metode CST terhadap citra yang telah dipertajam (enhancement) dengan teknik RGB. Evaluasi secara "eyeball" verification menunjukkan bahwa pada Gambar 5, hasil penajaman citra kanal IR1 HIMAWARI-8 pada 11 Jan 2018 jam 00, 06, 12, dan 18 UTC menggunakan aplikasi SATAID (panel kiri) mampu menggambarkan pola tingkat kecerahan yang sesuai dengan awan Cumuliform hasil perkiraan metode CST (panel kanan). Namun, jenis awan Stratiform tidak begitu jelas terlihat pada hasil enhancement. Hal ini disebabkan karena hanya band-IR saja yang dipakai dalam proses enhancement. Hasil enhancement menjadi lebih baik jika citra HIMAWARI-8 dilengkapi dengan band-VIS dan band-NIR (Near Infra-Red).

Walaupun metode komposit RGB telah dipakai dalam proses enhancement tetapi hasil di
Gambar 5 (panel kiri) tidak dapat menunjukkan jenis awan Cumuliform dan Stratiform secara kuantitatif. Oleh karena itu, di bagian selanjutnya, hasil penelitian ini fokus pada penggunaan metode CST untuk mengidentifikasi awan Cumuliform dan Stratiform.

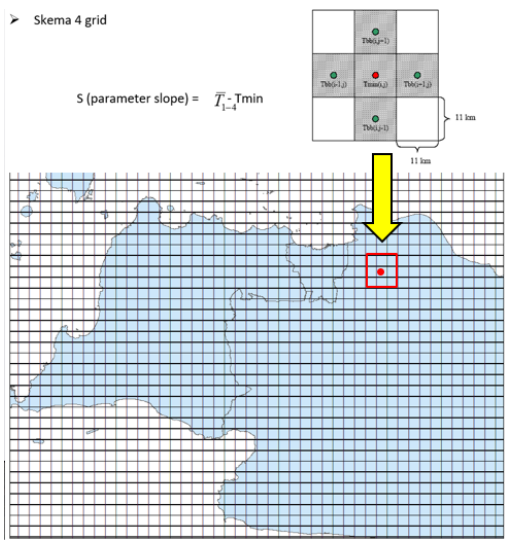

Gambar 1. Ilustrasi penerapan metode CST dengan skema 4 grid di semua pixel kanal IR1 HIMAWARI-8.

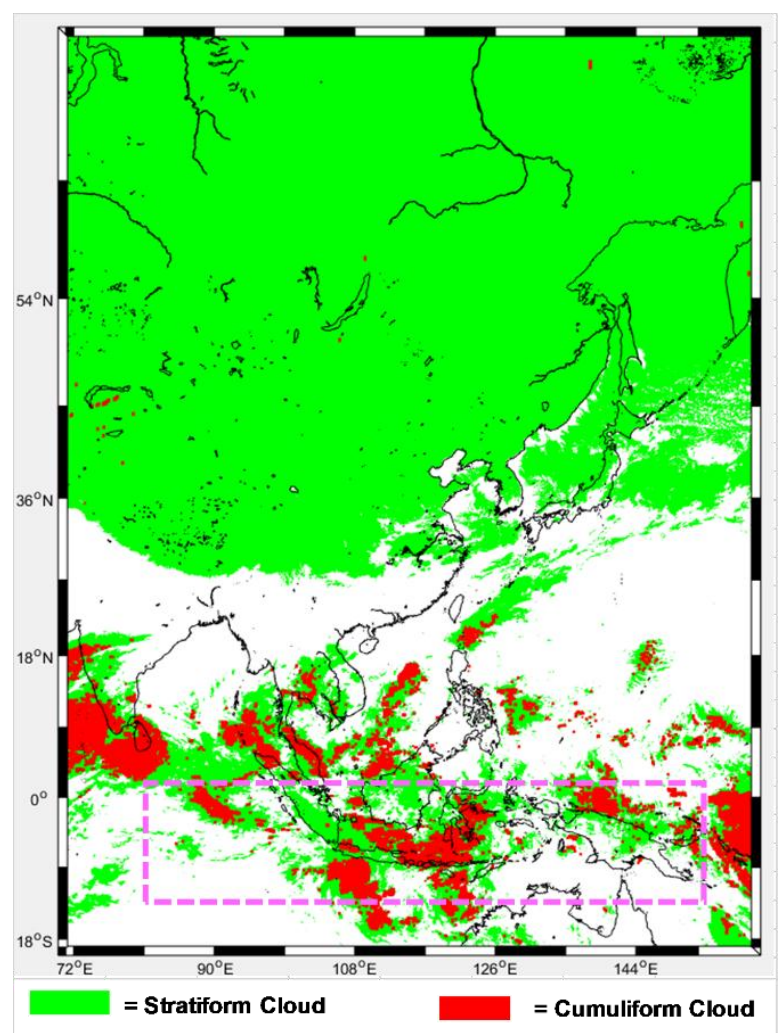

Gambar 2. Contoh hasil metode CST di domain akusisi HIMAWARI-8, dan kotak berwarna magenta adalah wilayah yang dianalisis pada penelitian ini. 


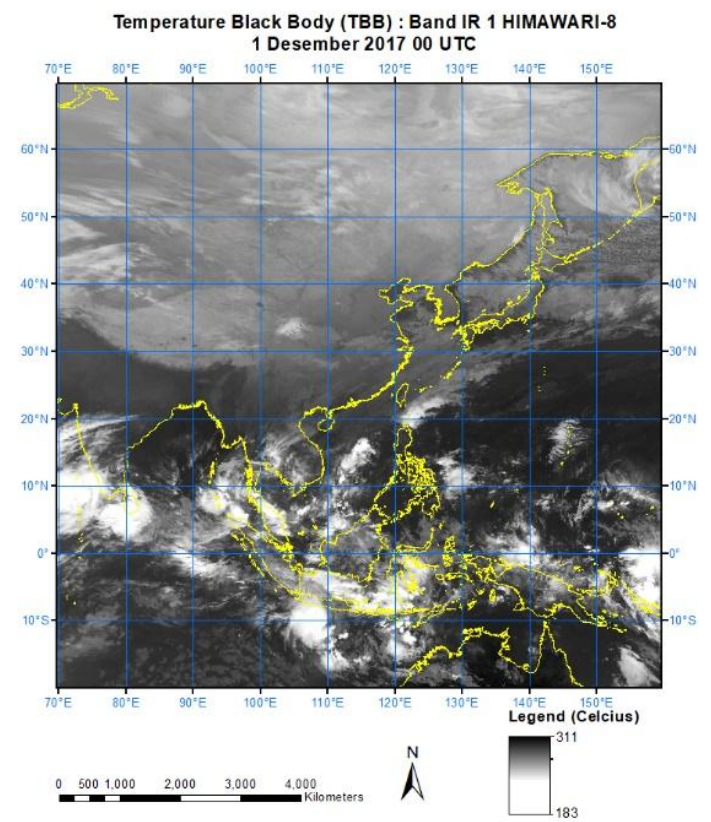

Gambar 3. Nilai TBB data IR1 HIMAWARI-8 pada 1 Des 2017 jam 00 UTC.

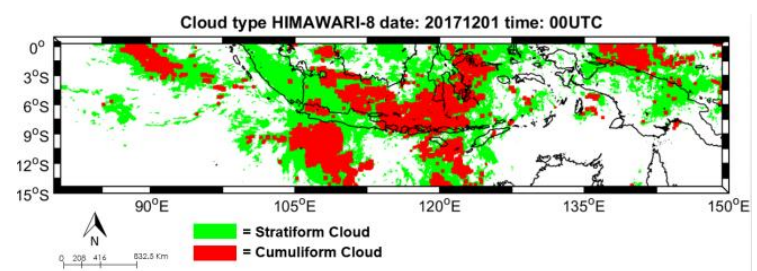

Gambar 4. Salah satu contoh hasil perkiraan jenis awan Stratiform dan Cumuliform dengan metode CST di selatan Indonesia pada 1 Des 2017 jam 00 UTC.

\subsection{Pola Rata-rata Jenis Awan per- Jam}

Bagian kedua dilanjutkan dengan menganalisis rata-rata jenis awan per-jam pengamatan dari jam 00 UTC (07.00 WIB) hingga 23 UTC (06.00 WIB), selama 90 hari dari 1 Des 2017 hingga 28 Feb 2018. Hasil menunjukkan bahwa secara spasial, pada tiap jam hanya muncul awan Stratiform (lihat Gambar 6). Perbedaan antar jam terlihat dari jumlah dan pola spasial awan Stratiform. Pada pagi hari antara jam 00 UTC hingga siang hari 06 UTC, awan Stratiform cenderung lebih banyak terdapat di bagian barat, selatan Indonesia khususnya di perairan laut Jawa, sedangkan pada siang hingga sore hari jumlah awan Stratiform banyak terlihat di bagian barat pulau Sumatera, laut Jawa, Kalimantan hingga menutupi wilayah pulau Jawa, Bali dan Nusa tenggara. Kemudian pada sore hingga malam hari jumlah awan ini semakin meningkat dan hampir menutupi semua wilayah Indonesia bagian selatan, kecuali di sekitar Laut Banda. Hal ini selaras dengan pola hujan yang ditunjukkan oleh Aldrian \& Susanto (2003), bahwa wilayah di sekitar Maluku dan laut Banda (pola hujan tipe C) mempunyai pola yang berkebalikan dengan tipe A. Dengan kata lain, pada saat tipe A sedang terdapat banyak awan berpeluang hujan (diasumsikan sama dengan curah hujan yang tinggi di wilayah ini), maka wilayah tipe $C$ menunjukkan hal yang sebaliknya karena tidak terdapat awan berpeluang hujan.

Selanjutnya, Gambar 7 masih berkaitan dengan Gambar 6, namun dihitung dengan merata-ratakan jumlah pixel awan Stratiform yang berhasil diidentifikasi di dalam domain $150 \mathrm{E}, 15 \mathrm{~S}-1 \mathrm{~N}$ atau lebih kurang terdapat sekitar 449.721 pixel. Hasilnya, secara temporal jumlah awan terbanyak terlihat pada waktu sore menjelang malam hari atau sekitar jam 08 UTC14 UTC dengan jumlah pixel awan Stratiform mencapai 200.000 pixel pada jam 09 dan 10 UTC. Pola peningkatan jumlah awan pada waktu sore hingga malam hari ini sama dengan temuan Kusumawati et al., 2008 yang melakukan kajian identifikasi awan dari citra MTSAT di sekitar Pulau Jawa dan menemukan bahwa terdapat peningkatan awan konvektif pada jam 18 WIB hingga 00 WIB dini hari, khususnya di daratan Pulau Jawa.

Meskipun secara rata-rata per-jam menunjukkan hanya awan Stratiform yang terlihat selama periode DJF 2017/2018, bukan berarti jenis awan Cumuliform tidak ada selama periode tersebut. Oleh karena itu untuk melengkapi hasil pola rata-rata per-jam maka selanjutnya pola spasial dan temporal jenis awan yang diduga dengan metode CST, juga diidentifikasi pada skala waktu yang lebih panjang, sekitar 10 harian atau dikenal sebagai dasarian. Terdapat sembilan dasarian pada periode DJF 2017/2018, yang disebut sebagai D-1 (tanggal 1-10 Des), D2 (11-20 Des), D-3 (21-31 Des), J-1 (1-10 Jan), J-2 (11-20 Jan), J-3 (21-31 Jan), F-1 (1-10 Feb), F-2 (11-20 Feb), dan F-3 (21-28 Feb). 

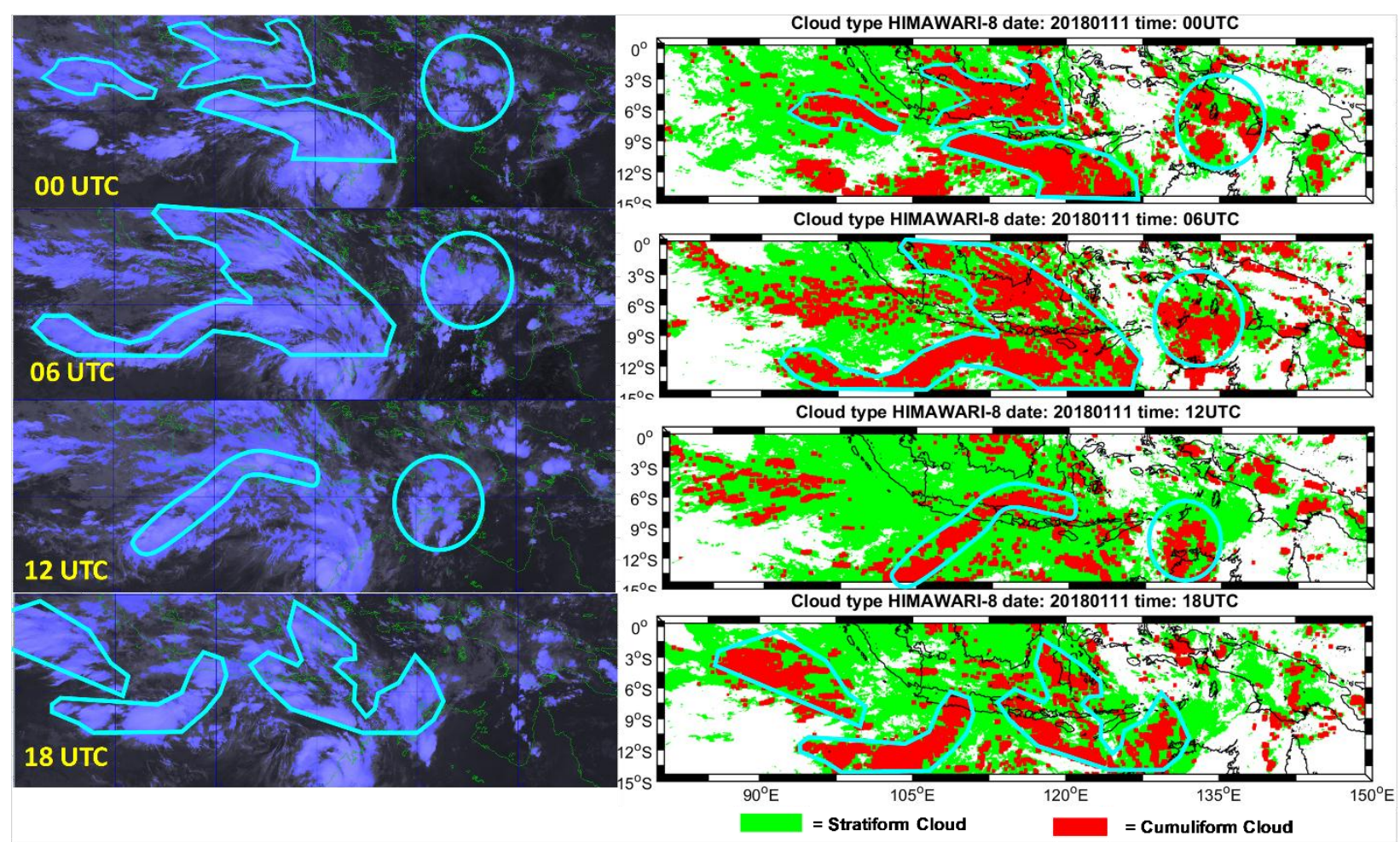

Gambar 5. Perbandingan hasil enhancement kanal IR1 citra HIMAWARI-8 menggunakan aplikasi SATAID (panel kiri) dengan perkiraan jenis awan metode CST (panel kanan) pada 11 Jan 2018 jam 00, 06, 12, dan18 UTC. Lingkaran dan poligon biru pada kedua panel menunjukkan kesesuaian spasial antara hasil enhancement dengan sebaran awan Cumuliform.

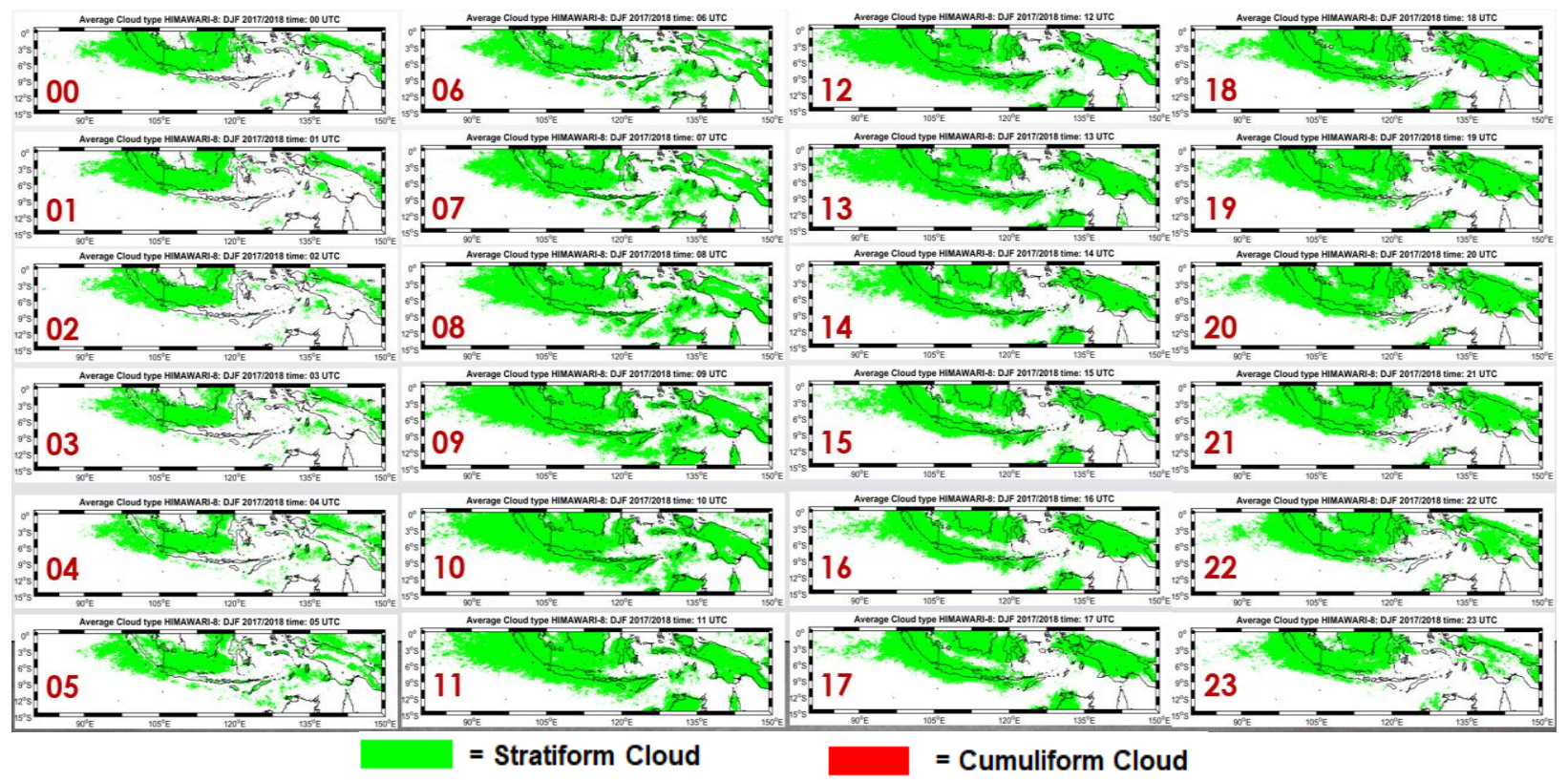

Gambar 6. Pola spasial awan Stratiform pada tiap jam 00-23 UTC di selatan Indonesia periode DJF 2017/2018. 
JUMLAH PIXEL AWAN STRATIFORM

(80E - 150E, 15S - 1N)

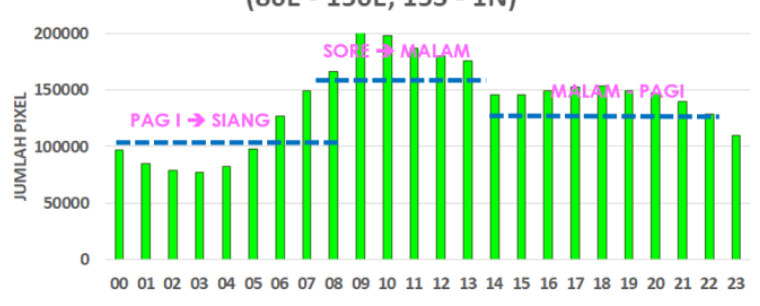

Gambar 7. Pola temporal jumlah pixel awan Stratiform pada tiap jam 00-23 UTC di selatan Indonesia periode DJF 2017/2018.

\subsection{Pola Rata-rata Jenis Awan per- Dasarian}

Bagian ketiga analisis klimatologi jenis awan dihitung berdasarkan skala waktu perdasarian. Hasilnya menunjukkan terdapat pola perubahan jumlah awan Stratiform dan Cumuliform dari D-1 hingga F-3 dimana jumlah awan Stratiform terlihat dominan di semua dasarian (lihat Gambar 8). Pada D-1 awan Stratiform dan Cumuliform hanya terlihat di atas laut Jawa dan bagian barat pulau Sumatera. Jumlah kedua jenis awan ini kemudian terus meningkat hingga mencapai puncaknya pada $\mathrm{J}$ 3. Periode J-3 ini diidentifikasi sebagai puncak musim hujan pada periode DJF 2017/2018. Pada Gambar 10, dasarian J-3 menunjukkan jumlah awan Cumuliform mencapai lebih dari 25.000 dari total 449.721 pixel yang ada di selatan Indonesia. Nilai ini kemudian menurun cukup signifikan pada F-2, biasanya hal ini dikaitkan dengan fase Break Monsoon dimana terjadi penurunan jumlah curah hujan sesaat pada periode musim hujan sebelum kemudian meningkat lagi pada F-3 (Surmaini \& Syahbuddin, 2016; Swarinoto \& Wirjohamidjojo, 2010).

Setelah mendapatkan pola klimatologi perdasarian maka selanjutnya dianalisis perbandingan jumlah awan Cumuliform dan Stratiform dengan jumlah curah hujan berdasarkan data curah hujan GSMaP. Tujuan nya untuk mengetahui seberapa akurat identifikasi jenis awan dengan metode CST terhadap jumlah curah hujan yang sebenarnya. Namun hanya jenis awan Cumuliform saja yang dianalisis karena jenis awan ini yang mempunyai peluang sangat besar untuk terbentuk nya hujan dengan intensitas tinggi (Tjasyono HK., 2012).

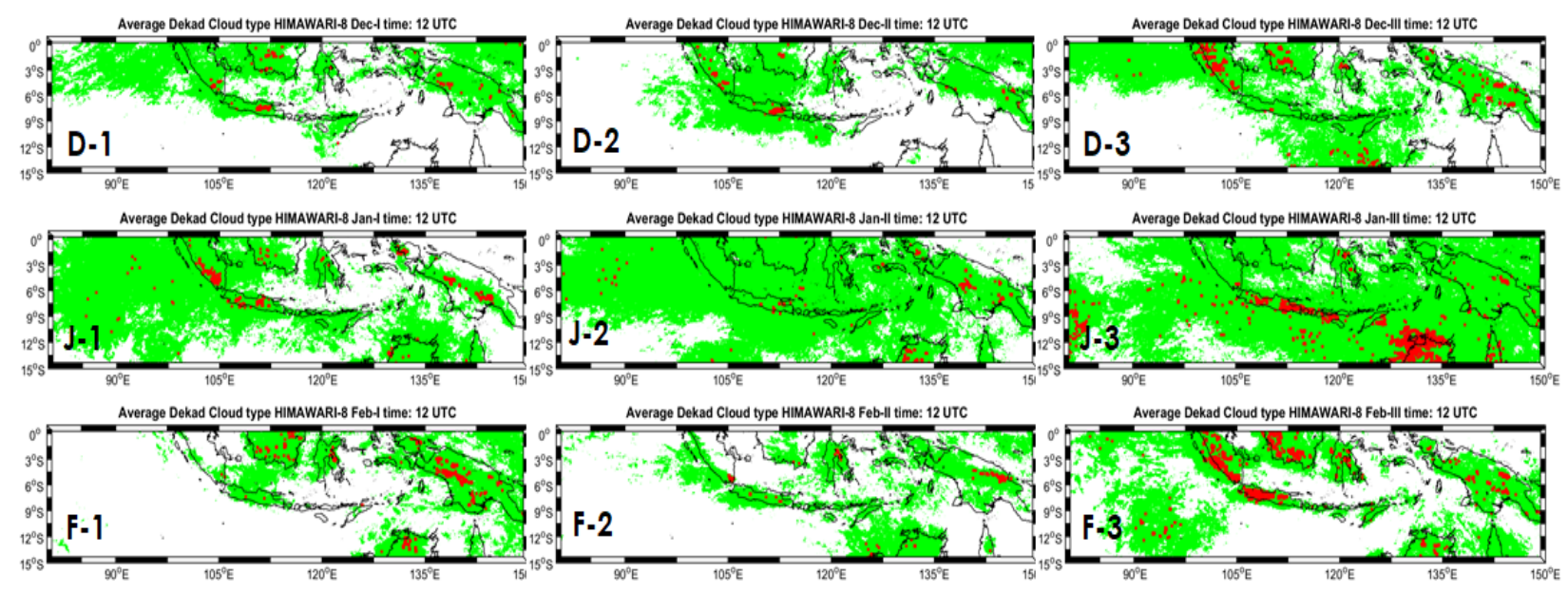

$=$ Stratiform Cloud $\quad$ = Cumuliform Cloud

Gambar 8. Pola spasial awan Stratiform dan Cumuliform dari dasarian pertama Des (D-1) hingga dasarian terakhir Feb (F-3) 2017/2018 di selatan Indonesia.

JUMLAH PIXEL AWAN CUMULIFORM

(80E - 150E, 15S - 1N)

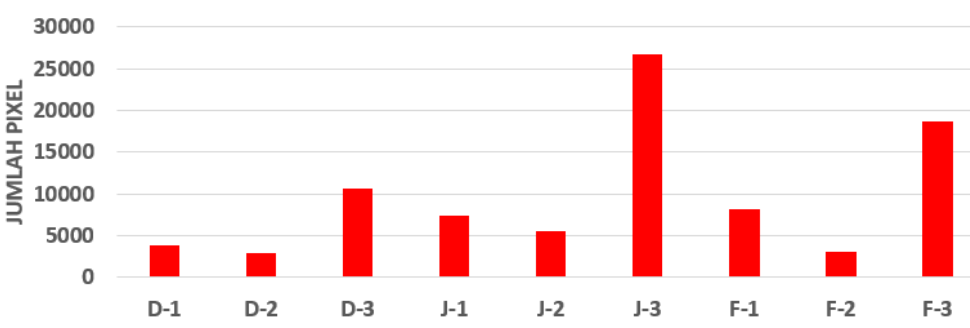

Gambar 9. Pola temporal jumlah pixel awan Cumuliform pada dasarian pertama Des (D-1) hingga dasarian terakhir Feb (F-3) 2017/2018 di selatan Indonesia. 


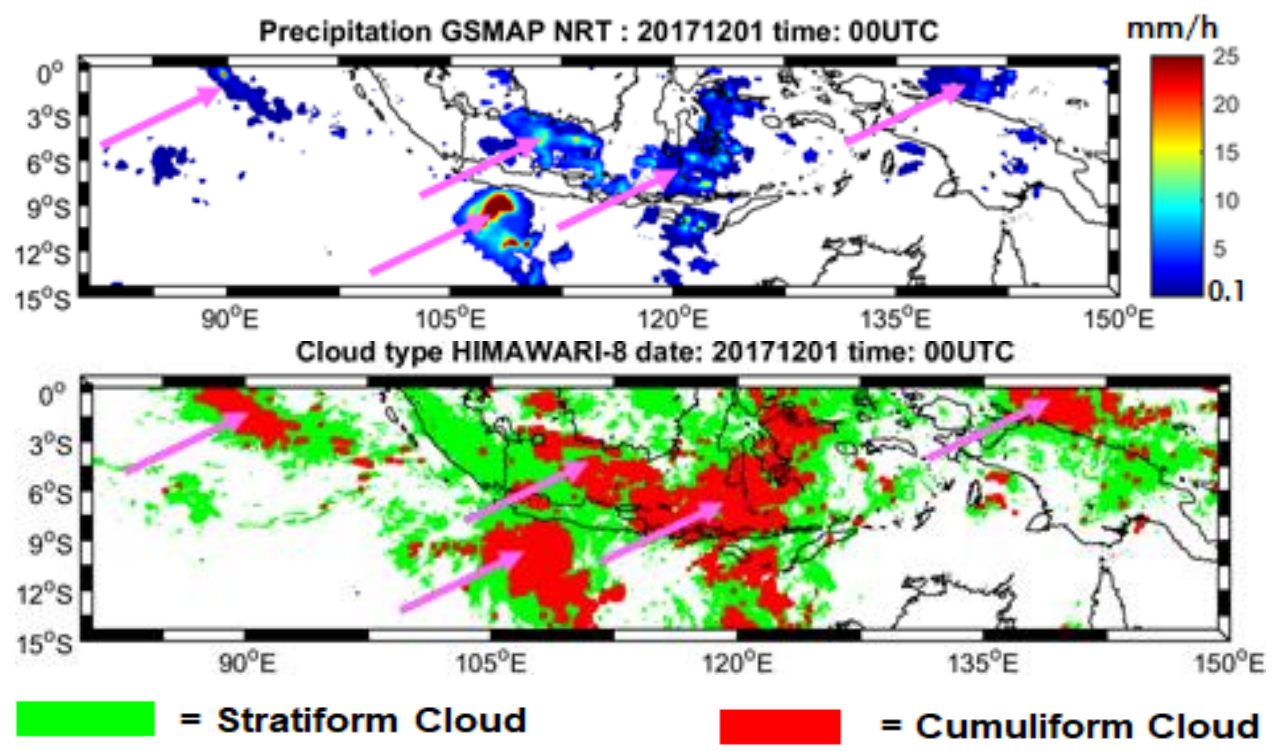

Gambar 10. Perbandingan sebaran pixe/ GSMaP dengan intensitas hujan $>0,1 \mathrm{~mm} / \mathrm{jam}$ (panel atas) terhadap sebaran awan Cumuliform dan Stratiform (panel bawah) pada 1 Des 2017 jam 00 UTC.

Tanda panah menunjukkan kesesuaian beberapa pola antara dua panel tersebut.

\subsection{Perbandingan Jumlah Pixel Awan Cumuliform terhadap Pixel Curah Hujan GSMaP \\ Evaluasi secara "eyeball" verification,} menunjukkan distribusi spasial pola curah hujan GSMaP berintensitas $>0,1 \mathrm{~mm} / \mathrm{jam}$ (selanjutnya ditulis GSMap $>0,1$ ), mirip dengan pola awan Cumuliform seperti terlihat pada (panel atas dan bawah Gambar 10). Sementara itu, warna putih pada pola curah hujan GSMaP NRT di Gambar 10 , adalah wilayah dengan intensitas curah hujan kurang dari $0,1 \mathrm{~mm} / \mathrm{jam}$. Umumnya, wilayah ini berasosiasi dengan lokasi awan Stratiform.

Hasil pada Gambar 10 ini selanjutnya dibuktikan secara statistik dengan mengukur tingkat korelasi antara jumlah pixel awan Cumuliform dengan jumlah pixel GSMaP $>0,1$. Pada Gambar 11 hingga Gambar 18 diperoleh hasil analisis korelasi antara keduanya selama 90 hari pengamatan dari 1 Des 2017 hingga 28 Feb 2018, dipilih empat jam pengamatan utama, jam 00, 06, 12, dan 18 UTC untuk mewakili kondisi pagi, siang sore dan malam hari.

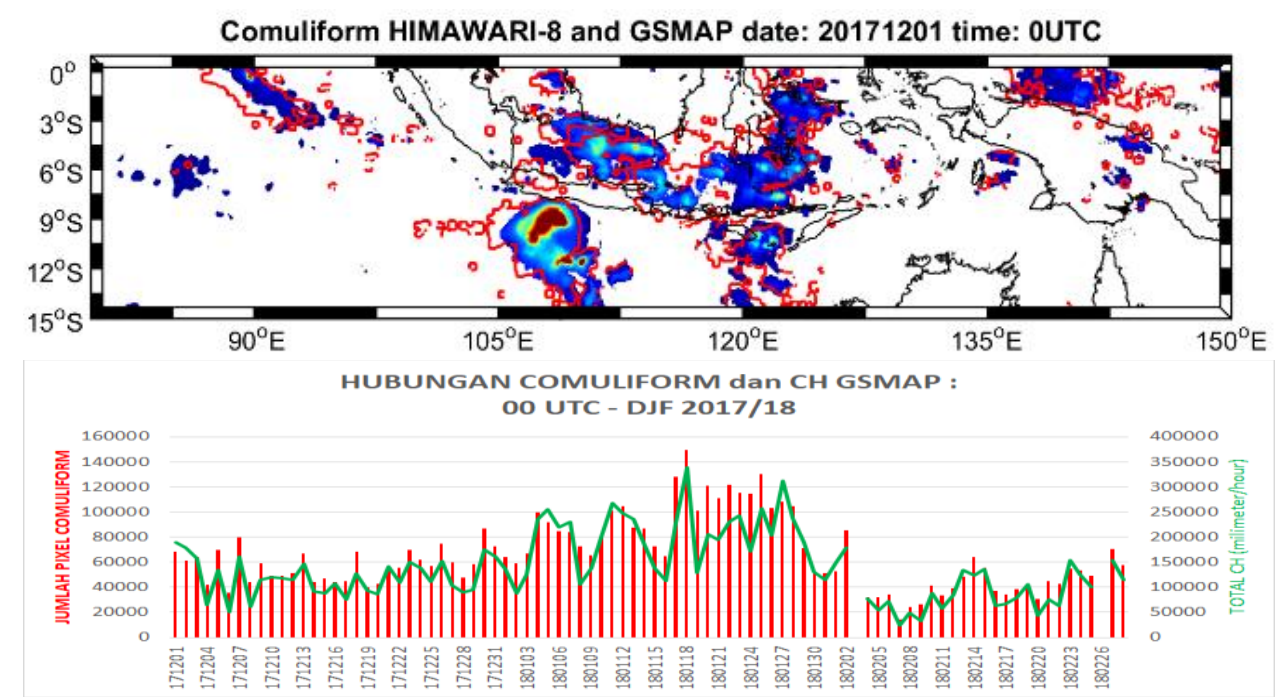

Gambar 11. (Panel atas) Sebaran curah hujan GSMaP $>0,1 \mathrm{~mm} / \mathrm{jam}$ dan kontur merah menunjukkan poligon awan Cumuliform; (Panel bawah) hubungan jumlah pixel awan Cumuliform dengan hujan GSMaP (milimeter) pada tiap jam 00 UTC selama 90 hari periode DJF 2017/2018. 
Hasil korelasi menunjukkan bahwa terdapat hubungan yang kuat $(r>0,75)$ antara jumlah pixel awan Cumuliform terhadap jumlah pixel GSMaP $>0,1$, untuk rata-rata pada empat jam pengamatan utama. Korelasi tertinggi diperoleh pada pagi hari 00 UTC dan terendah pada sore hari 12 UTC. Hal ini disebabkan karena variabilitas curah hujan pada sore hari relatif lebih besar dibandingkan pada pagi hari, sehingga tidak semua awan Cumuliform yang diperoleh dari metode CST berasosiasi langsung dengan curah hujan dilokasi yang sama dari citra GSMaP.

Namun demikian hubungan korelasi ini hanya sebatas menggambarkan seberapa mirip perkiraan awan Cumuliform terhadap kejadian curah hujan GSMaP>0,1 pada tiap waktu pengamatan sedangkan apakah pada setiap pixel yang diidentifikasi sebagai awan Cumuliform akan selalu menjadi curah hujan dengan intensitas $>0,1 \mathrm{~mm} / \mathrm{jam}$ tidak dapat disimpulkan dari pola korelasi ini. Setidaknya, berdasarkan hasil statistik korelasi tersebut, diketahui bahwa kemunculan awan Cumuliform berhubungan kuat dengan terjadinya hujan berintensitas sedang hingga sangat lebat, di suatu wilayah (Kusumawati et al., 2008).

Hubungan statistik yang diuraikan di atas menunjukkan metode CST lebih terukur dari sekedar metode enhancement dengan teknik RGB. Selain itu metode CST pada penelitian ini, dianggap masih relevan digunakan sebagai salah satu cara untuk mengidentifikasi jenis awan ataupun intensitas hujan, meskipun metode CST ini sendiri telah dikembangkan menjadi CST modify (CSTm) dan CSTm+Growth Factor (Mulsandi et al., 2020).

Korelasi kuat yang ditunjukkan oleh pola spasial awan Cumuliform dengan GSMaP $>0,1$ identik dengan pola perkembangan kejadian MCC yang juga dibandingkan dengan pola curah hujan GSMaP (Muhlis \& Mulsandi, 2017, Septiadi \& Nugraha, 2019 dan Perdana et al., 2019). Pada ketiga kajian tersebut, distribusi pola MCC mulai dari tumbuh hingga matang (mature) sebanding dengan pola spasial curah hujan GSMaP dengan intensitas besar dari nol hingga

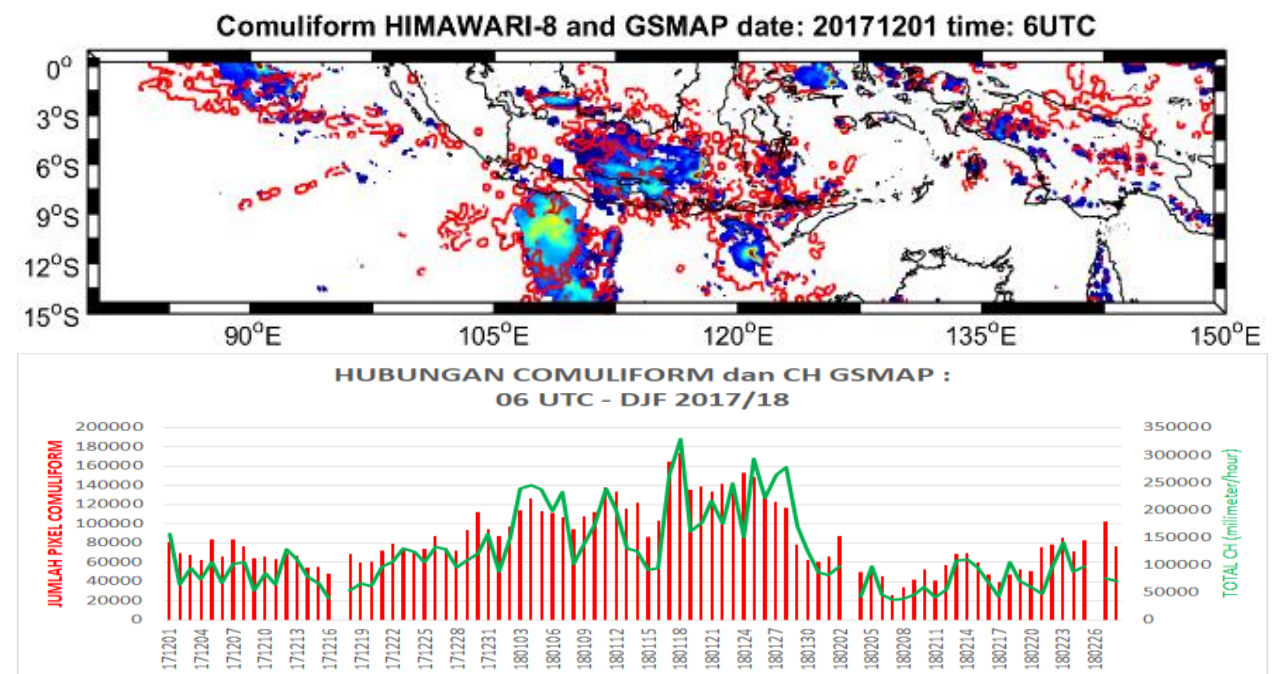

Gambar 12. Sama dengan Gambar 12 tetapi untuk jam 06 UTC

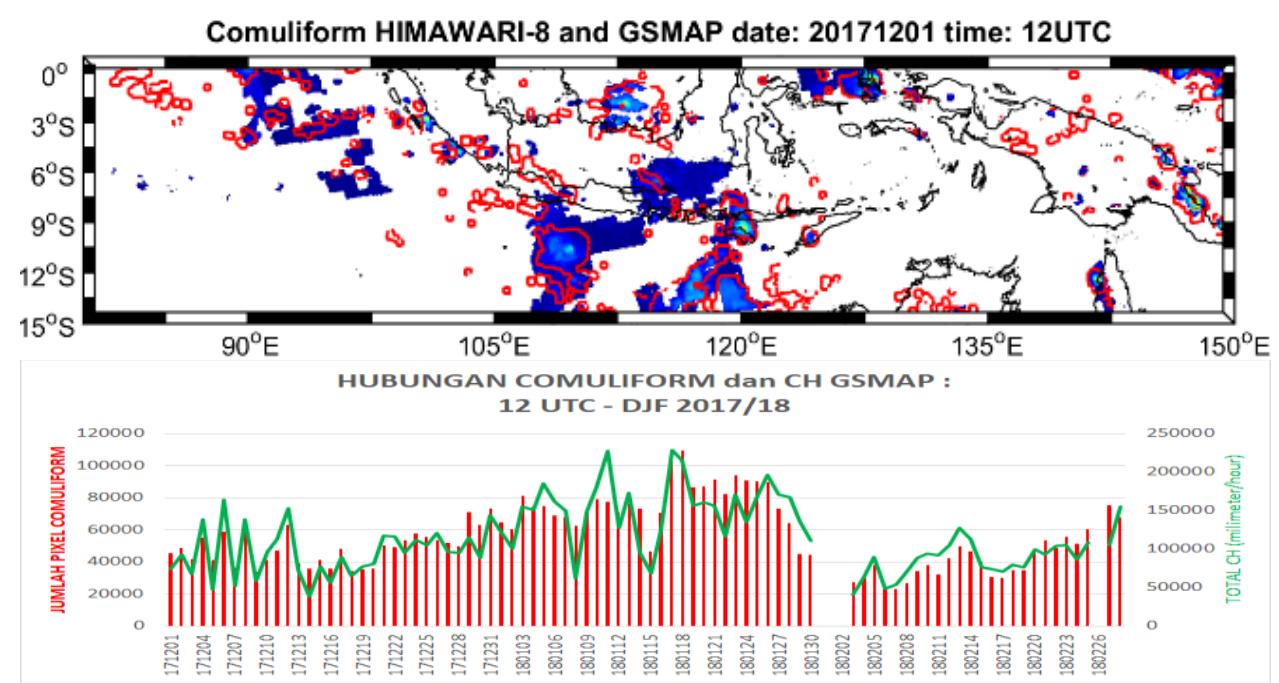

Gambar 13. Sama dengan Gambar 12 tetapi untuk jam 12 UTC. 
$30 \mathrm{~mm} / \mathrm{jam}$. Misal menurut Septiadi \& Nugraha, 2019, pada 27-28 Desember 2018 pola MCC mature teridentifikasi dari kanal IR HIMAWARI-8, terjadi pada pukul 00 - 06 waktu setempat (18-00 UTC) yang ditandai dengan terjadinya hujan mencapai $30 \mathrm{~mm} / \mathrm{jam}$.

Namun, kajian pola perkembangan MCC yang dibahas pada pada kajian Muhlis \& Mulsandi, 2017, Septiadi \& Nugraha, 2019 dan Perdana et al., 2019, tidak memberikan secara spesifik berapa banyak pixel pola MCC dari kanal
IR1 HIMAWARI-8 yang berasosiasi dengan pola curah hujan yang diukur oleh satelit GSMaP, sehingga secara statistik tidak dapat digambarkan dalam suatu nilai. Oleh karena itu, hasil penelitian ini memberikan suatu sudut pendekatan baru untuk mengidentifikasi berapa besar akurasi yang menunjukkan kesesuaian kanal IR1 HIMAWARI-8 terhadap suatu fenomena seperti MCC ataupun sebatas identifikasi jenis awan Cumuliform dan Stratiform.

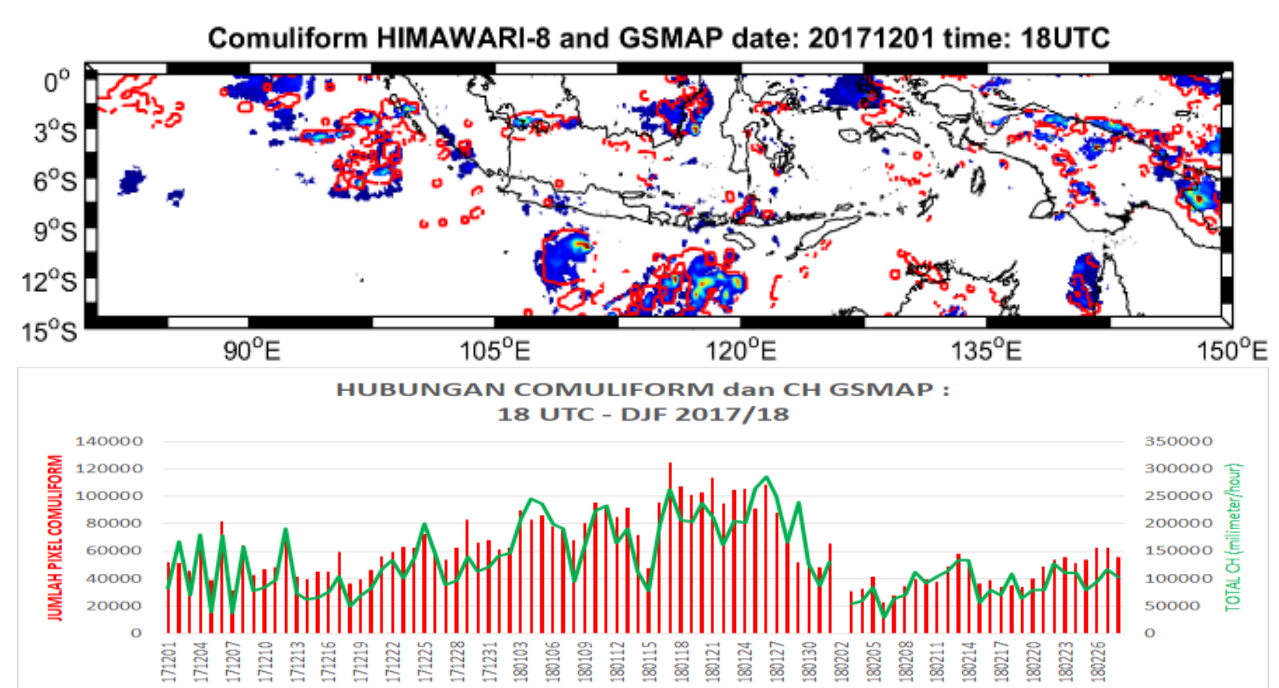

Gambar 14. Sama dengan Gambar 12 tetapi untuk jam 18 UTC

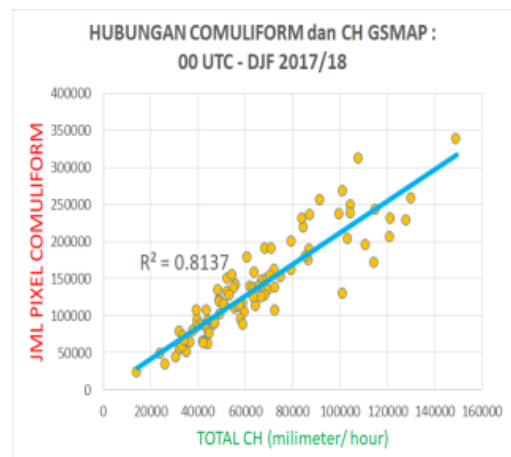

(a) 00 UTC

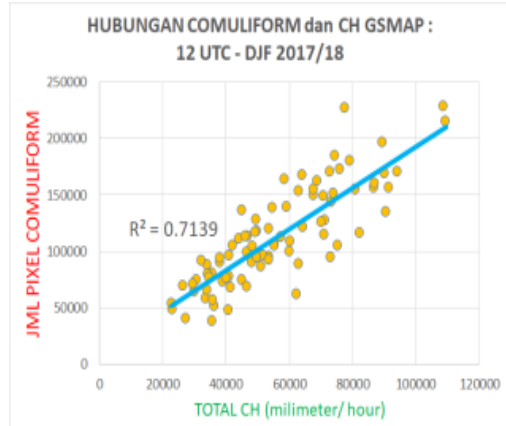

(c) 12 UTC

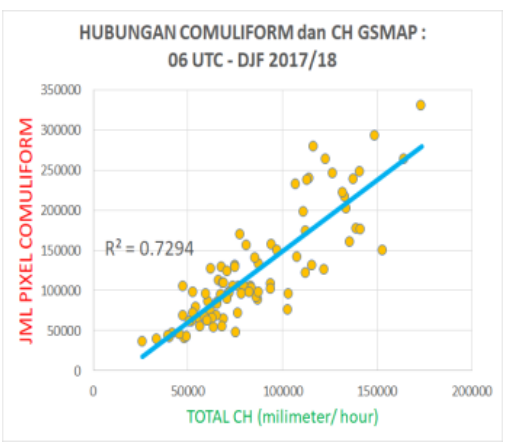

(b) 06 UTC

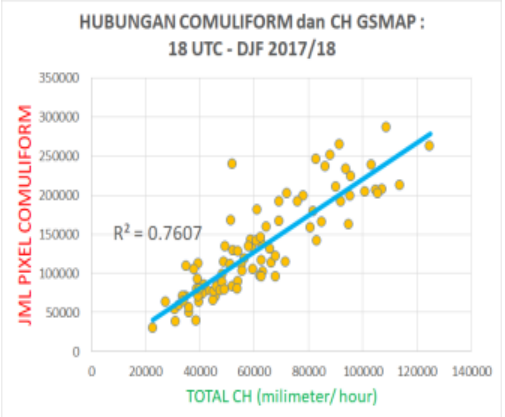

(d) 18 UTC

Gambar 15. Korelasi antara jumlah pixel GSMaP dengan curah hujan $>0,1 \mathrm{~mm} / \mathrm{jam}$ terhadap jumlah pixel awan Cumuliform selama 90 hari pengamatan pada periode musim hujan DJF 2017/2018, dengan (a) jam 00 UTC ( $r=0,87)$, (b) jam 06 UTC ( $r=0,72)$, (c) jam 12 UTC ( $r=0,71)$ dan (d) jam 18 UTC $(r=0,76)$. 


\subsection{Pola Propagasi Barat - Timur Awan Stratiform dan Cumuliform}

Bagian terakhir dari identifikasi pola spasial dan temporal jenis awan selama periode musim hujan DJF 2017/2018 ditinjau dari pola propagasi atau perambatan awan yang bergerak dari barat ke timur, di bagian selatan Indonesia, atau dikenal sebagai fenomena MJO. Pola spasial dan temporal propagasi tersebut disajikan dalam diagram Hovmoller (Gambar 16).
Pada diagram tersebut pola awan Stratiform dan Cumuliform bergerak dari barat ke timur di bagian selatan Indonesia yang terjadi dari pagi hingga malam hari. Evaluasi secara "eyeball" verification menunjukkan jumlah awan yang merambat pada jam 12 UTC dan 18 UTC terlihat lebih banyak dibandingkan jam pengamatan lainnya. Hal ini sesuai dengan temuan pada bagian 3.2 bahwa secara rata-rata per-jam jumlah awan pada sore hari cenderung lebih banyak dibandingkan jumlah awan pada pagi, siang atau malam hari.

\section{Diagram Hovmoller: Time - Longitude Jumlah awan Cumuliform dan Stratiform}

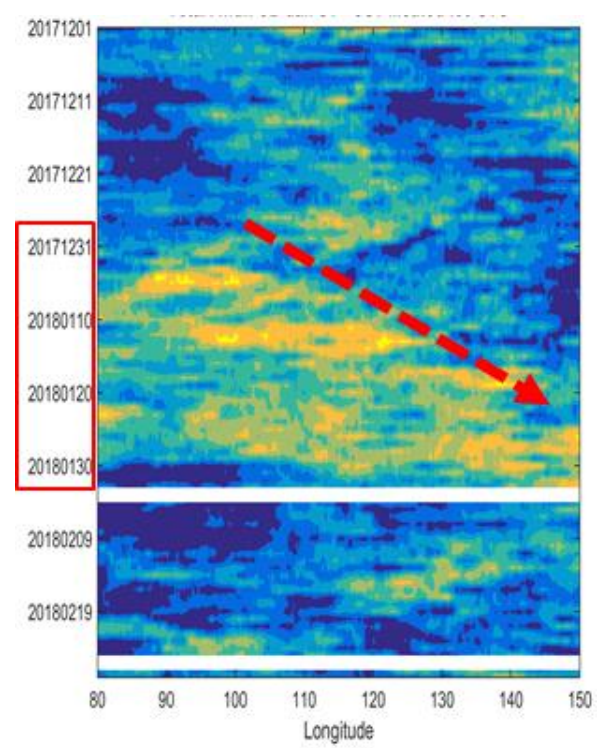

a) 00 UTC

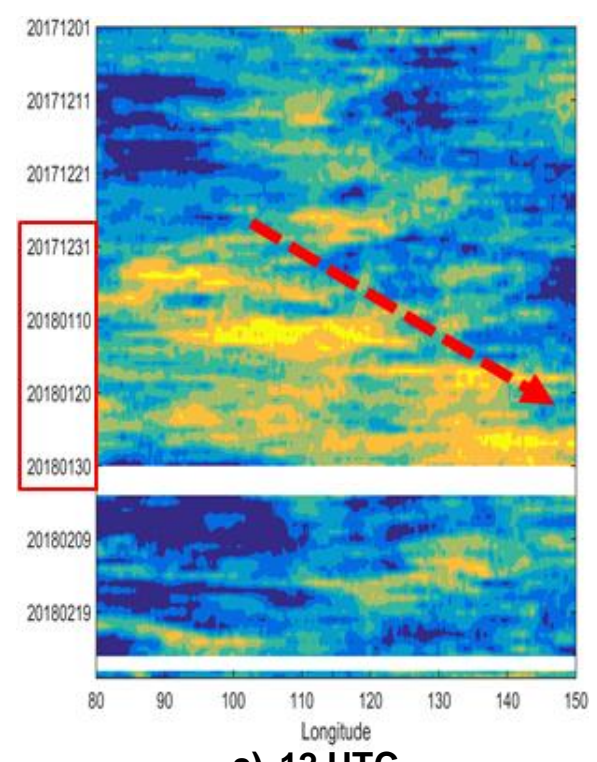

c) 12 UTC

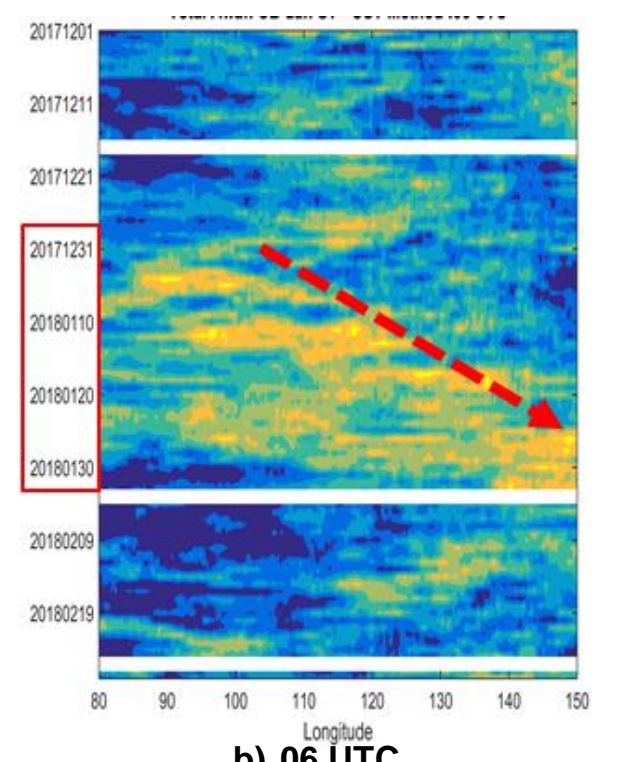

b) 06 UTC

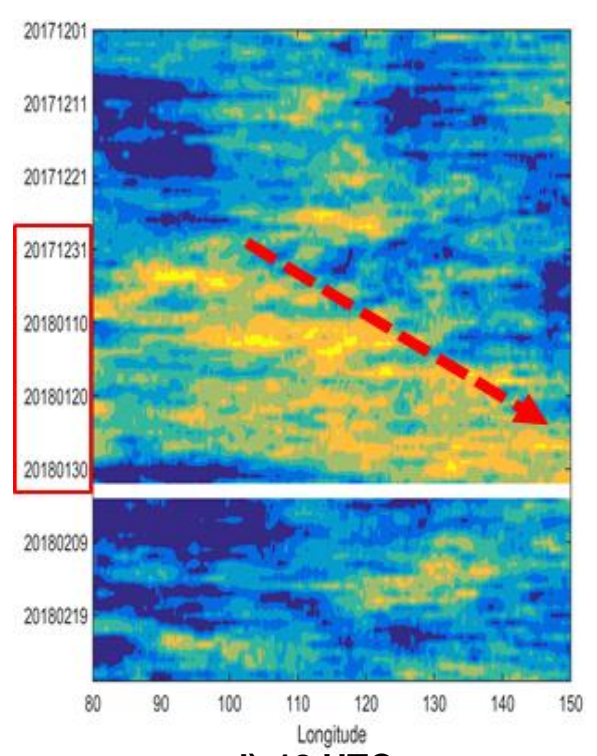

d) 18 UTC

\section{Jumlah \\ pixel \\ awan}

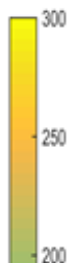

150

100

Gambar 17. Pola rata-rata perambatan jumlah awan Stratifrom dan Cumuliform selama periode DJF 2017/2018 pada jam: (a) 00 UTC, (b) 06 UTC, (c) 12 UTC dan (d) 18 UTC yang disajikan dalam diagram Hovmoller. Sumbu $y$ (atas ke bawah) adalah waktu (hari) yang menujukan 1 Des 2017 hingga 28 Feb 2018, sumbu $x$ (kiri ke kanan) menunjukkan bujur $80 \mathrm{E}-150 \mathrm{E}$ atau bagian barat hingga timur Indonesia, sedangkan warna biru ke kuning menunjukkan jumlah pixel awan pada tiap bujur dan tiap waktu. 
(RMM1, RMM2) phase space for 1-Jan-2018 to 31-Mar-2018

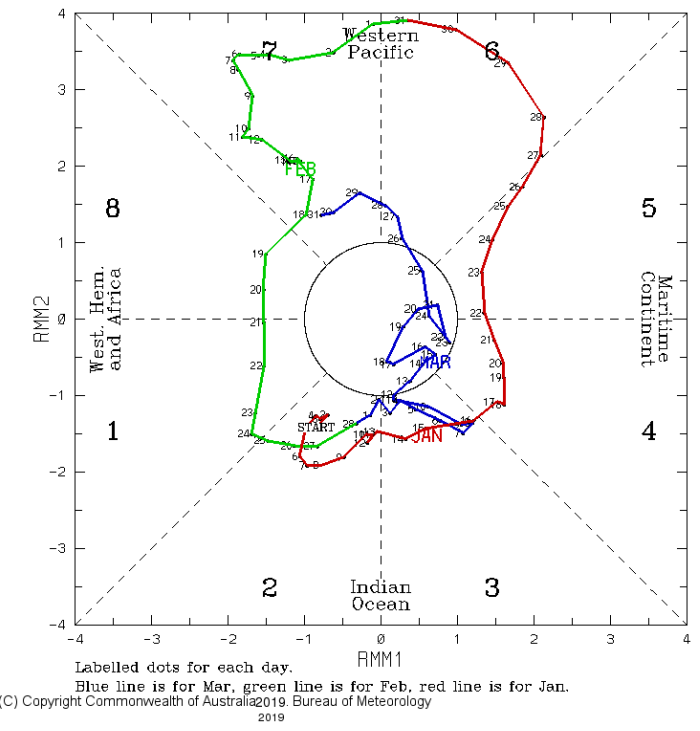

Gambar 18. Pola propagasi MJO yang dinyatakan dalam indeks RMM pada 1 Jan 2018 hingga 31 Maret 2018. Propagasi MJO pada bulan Jan ditandai oleh garis merah (http://www.bom.gov.au/climate/mjo/).

Meskipun evaluasi propagasi dilakukan secara "eyeball" verification, namun hal ini bisa dikonfirmasi dari Gambar 18. Propagasi yang terlihat pada Gambar 17 sesuai dengan fase aktif MJO periode 1 Jan 2018 - Mar 2018 (Gambar 18). Selama Jan 2018, MJO aktif dengan indeks Realtime Multivariate MJO (RMM) lebih dari 1, mulai melintasi wilayah barat Indonesia di sekitar Indian Ocean (fase 3) kemudian masuk ke wilayah Indonesia atau BMI (fase 4 dan 5), hingga ke bagian timur Indonesia atau bagian barat Samudera Pasifik (fase 6).

\section{KESIMPULAN}

Berdasarkan hasil yang diperoleh dapat disimpulkan bahwa, metode CST mampu menentukan awan-awan Stratiform dan Cumuliform. Secara "eyeball" verification, metode enhancement dengan teknik RGB pada aplikasi SATAID juga menunjukkan pola serupa. Selanjutnya, terkait pola spasial dan temporal dari jenis awan yang diduga menggunakan metode CST, selama periode musim hujan 2017/2018 di selatan Indonesia dapat disimpulkan bahwa:

- Di bagian barat Indonesia (khususnya laut Jawa dan pesisir barat Sumatera) selalu ditutupi awan Stratiform, baik pagi, siang, sore atau malam hari;

- Puncak musim hujan DJF 2017/2018, diketahui terjadi pada Jan dasarian ketiga (tanggal 21-31 Jan 2018) karena jumlah awan Cumuliform dan Stratiform paling banyak ditemukan pada periode tersebut;

- Awan Cumuliform berdasarkan metode CST berasosiasi kuat dengan pola curah hujan GSMAP $>0.1 \mathrm{~mm} / \mathrm{jam}$, hubungannya secara statistik menunjukkan secara rata-rata pada empat jam pengamatan utama: 00, 06, 12, dan 18 UTC berkorelasi kuat dengan $r>0.76$;

- Perkiraan jenis awan dengan metode CST juga dapat merepresentasikan fenomena MJO yang ditandai dengan perambatan awan-awan Stratiform dan Cumuliform dari bagian barat hingga timur Indonesia saat periode musim hujan.

\section{DAFTAR PUSTAKA}

Adler, R.F., Negri, A.J., 1988. A Satellite Infrared Technique to Estimate Tropical Convective and Stratiform Rainfall. J. Appl. Meteorol. 27, 30-51. doi:10.1175/15200450(1988)027<0030:ASITTE>2.0.CO;2

Aldrian, E., Susanto, R., 2003. Identification of three dominant rainfall regions within Indonesia and their relationship to sea surface temperature. Int. J. Climatol. 23, 1435-1452. doi: 10.1002/joc.950

Hastuti, M.I., Azzahra, A.N., 2017. Pemanfaatan Data Satelit Himawari-8 untuk Estimasi Curah Hujan dengan Metode Autoestimator di Kalianget, Madura. Semin. Nas. Penginderaan Jauh Ke-4 Tahun 20177.

Jensen, J.R., Lulla, K., 1987. Introductory digital image processing: A remote sensing perspective. Geocarto Int. 2, 65-65. doi: 10.1080/10106048709354084

Kharisma, S., Widomurti, L., 2018. Analisis Hujan Lebat dengan Menggunakan Data Citra Satelit di Kabupaten Banjarnegara (Studi Kasus 18 Juni 2016). J. Mater. dan Energi Indones. $8, \quad 7 . \quad$ doi: 10.24198/jmei.v8i01.12108.g8384

Kushardono, D., 2012. Kajian Satelit Penginderaan Jauh Cuaca Generasi Baru Himawari 8 dan 9. J. Teknol. Dan Data Penginderaan Jauh III, 10.

Kusumawati, Y., Effendy, S., Aldrian, E., 2008. Variasi Spasial dan Temporal Hujan Konvektif di Pulau Jawa Berdasarkan Citra Satelit. J. Agromet 22, 15. doi: 10.29244/j.agromet.22.1.\%25p

Madden, R.A. dan Julian, P.R., 1972. Description of global-scale circulation cells in the tropics with a 40-50 day period. Journal of the Atmospheric Sciences, 29(6), pp.11091123.

Mikuš, P., Strelec Mahović, N., 2013. Satellitebased overshooting top detection methods 
and an analysis of correlated weather conditions. Atmospheric Res. 123, 268280. doi: 10.1016/j.atmosres.2012.09.001

Muhlis, A., Mulsandi, A., 2017. Distribusi Spasial dan Temporal Mesoscale Convective Complex (Mcc) di Indonesia Selama Periode MJO Menggunakan Citra Satelit. J. Meteorologi Klimatologi dan Geofisika 4 (1). doi: 10.36754/jmkg.v4i1.36

Mulsandi, A., Mamenun, M., Fitriano, L., Hidayat, R., 2020. Perbaikan Estimasi Curah Hujan Berbasis Data Satelit Dengan Memperhitungkan Faktor Pertumbuhan Awan. JSTMC 20, 67-78. doi: 10.29122/jstmc.v20i2.3810

Parwati, S., Ayu DS, K., Kartasamita, M., 2009. Penentuan Hubungan antara Suhu Kecerahan Data MTSAT dengan Curah Hujan Data QMORPH. J. Penginderaan Jauh 6(11).

Paski, J.A.I., Sepriando, A.,Pertiwi D.A.S., 2017. Pemanfaatan Teknik RGB Pada Citra Satelit Himawari-8 Untuk Analisis Dinamika Atmosfer Kejadian Banjir Lampung 20 - 21 Februari 2017. J. Meteorologi Klimatologi dan Geofisika Vol. 4 No. 3. doi: 10.36754/jmkg.v4i3.48

Perdana, I.F.P., Rismana, Y.I., Prasetya F.A., Mulsandi, A., 2019. Studi Kejadian Mesoscale Convective Complex (MCC) di Wilayah Papua Bagian Selatan pada 9-10 Mei 2018. J. Meteorologi Klimatologi dan Geofisika Vol. 6 No. 1. doi: 10.36754/jmkg.v6i1.115

Putri, R.J.A., 2016. Pemanfaatan Data Satelit Himawari-8 untuk Analisis Kejadian Hujan Sangat Lebat di Kabupaten Nabire, Papua
Tengah (Tanggal 12, 21, dan 22 Maret 2016). Pros. SNSA 2016.

Rizkiafama, V.A., Dzikiro, T.K., Safril, A., 2019. Pemanfaatan Data Satelit Himawari-8 Serta Data Curah Hujan dan Hari Hujan Bulanan Dalam Analisis Kejadian Banjir Kota Padang, 9 September 2017 dan 26 September 2018. Pros. SNFA Semin. Nas. Fis. dan Apl. 3, 264. doi: 10.20961/prosidingsnfa.v3i0.28560

Septiadi, D., Nugraha, Y., 2019. Identifikasi Mesoscale Convective Complex (MCC) dan Dampaknya Terhadap Curah Hujan Di Benua Maritim Indonesia (BMI) Sepanjang Tahun 2018. J. Meteorologi dan Geofisika Vol. 20 No. 1, p73-80

Surmaini, E., Syahbuddin, H., 2016. Kriteria Awal Musim Tanam: Tinjauan Prediksi Waktu Tanam Padi di Indonesia. J. Penelit. dan Pengemb. Pertan. 35, 47. doi: 10.21082/jp3.v35n2.2016.p47-56

Swarinoto, Y.S., Wirjohamidjojo, D.S., 2010. Iklim kawasan Indonesia: dari aspek dinamiksinoptik. Jakarta: Badan Meteorologi, Klimatologi, dan Geofisika.

Tjasyono HK., B., 2012. Mikrofisika awan dan hujan. Jakarta: Badan Meteorologi Klimatologi dan Geofisika.

Wicaksono, H., Sadarang, F.R., Fadlan, A., 2018. Analisis Hujan Es di Kota Lubuklinggau Dengan Memanfaatkan Data Citra Satelit Himawari-8 dan Radiosonde. Pros. SNFA Semin. Nas. Fis. Dan Apl. 2018.

Wirjohamidjojo, D.S., Swarinoto, Y.S., 2007. Praktek Meteorologi Pertanian. Jakarta: Badan Meteorologi Klimatolologi dan Geofisika. 